Cochrane Database of Systematic Reviews

\title{
Hypertonic versus near isotonic crystalloid for fluid resuscitation in critically ill patients (Review)
}

Bunn F, Roberts IG, Tasker R, Trivedi D

Bunn F, Roberts IG, Tasker R, Trivedi D.

Hypertonic versus near isotonic crystalloid for fluid resuscitation in critically ill patients.

Cochrane Database of Systematic Reviews 2004, Issue 3. Art. No.: CD002045.

DOI: 10.1002/14651858.CD002045.pub2.

www.cochranelibrary.com 
TABLE OF CONTENTS

HEADER

ABSTRACT

PLAIN LANGUAGE SUMMARY

BACKGROUND

OBJECTIVES

METHODS

RESULTS

DISCUSSION

AUTHORS' CONCLUSIONS

ACKNOWLEDGEMENTS

REFERENCES

CHARACTERISTICS OF STUDIES

DATA AND ANALYSES

Analysis 1.1. Comparison 1 Hypertonic versus isotonic crystalloid, Outcome 1 Death.

Analysis 1.2. Comparison 1 Hypertonic versus isotonic crystalloid, Outcome 2 Poor outcome (GOS). APPENDICES

FEEDBACK

WHAT'S NEW

HISTORY

CONTRIBUTIONS OF AUTHORS

DECLARATIONS OF INTEREST

SOURCES OF SUPPORT

INDEX TERMS

1

1

2

3

3

3

4

4

5

5

6

7 
[Intervention Review]

\section{Hypertonic versus near isotonic crystalloid for fluid resuscitation in critically ill patients}

Frances Bunn ${ }^{1}$, Ian G Roberts ${ }^{2}$, Robert Tasker ${ }^{3}$, Daksha Trivedi ${ }^{1}$

${ }^{1}$ Centre for Research in Primary and Community Care, University of Hertfordshire, Hatfield, UK. ${ }^{2}$ Cochrane Injuries Group, London School of Hygiene \& Tropical Medicine, London, UK. ${ }^{3}$ University of Cambridge School of Clinical Medicine, Department of Paediatrics, Cambridge, UK

Contact address: Frances Bunn, Centre for Research in Primary and Community Care, University of Hertfordshire, College Lane, Hatfield, Hertfordshire, AL10 9PN, UK. f.bunn@herts.ac.uk.

Editorial group: Cochrane Injuries Group

Publication status and date: Edited (no change to conclusions), published in Issue 4, 2008.

Citation: Bunn F, Roberts IG, Tasker R, Trivedi D. Hypertonic versus near isotonic crystalloid for fluid resuscitation in critically ill patients. Cochrane Database of Systematic Reviews 2004, Issue 3. Art. No.: CD002045. DOI: 10.1002/14651858.CD002045.pub2.

Copyright @ 2008 The Cochrane Collaboration. Published by John Wiley \& Sons, Ltd.

\section{A B S T R A C T}

\section{Background}

Hypertonic solutions are considered to have a greater ability to expand blood volume and thus elevate blood pressure and can be administered as a small volume infusion over a short time period. On the other hand, the use of hypertonic solutions for volume replacement may also have important disadvantages.

\section{Objectives}

To determine whether hypertonic crystalloid decreases mortality in patients with hypovolaemia.

\section{Search methods}

We searched the Cochrane Injuries Group's specialised register, MEDLINE, EMBASE, The Cochrane Library, issue 3, 2007, The National Research Register issue 3, 2007 and the British Library's Electronic Table of Contents ZETOC. We also checked reference lists of all articles identified. The searches were last updated in October 2007

\section{Selection criteria}

Randomised trials comparing hypertonic to isotonic and near isotonic crystalloid in patients with trauma or burns or who were undergoing surgery.

\section{Data collection and analysis}

Two authors independently extracted the data and assessed the quality of the trials.

\section{Main results}

Fourteen trials with a total of 956 participants are included in the meta-analysis. The pooled relative risk (RR) for death in trauma patients was 0.84 (95\% confidence interval [Cl] 0.69 to1.04); in patients with burns 1.49 (95\% $\mathrm{Cl} 0.56$ to 3.95$)$; and in patients undergoing surgery $0.51(95 \% \mathrm{Cl} 0.09$ to 2.73$)$. In the one trial that gave data on disability using the Glasgow outcome scale, the relative risk for a poor outcome was $1.00(95 \% \mathrm{Cl} 0.82$ to 1.22$)$.

\section{Authors' conclusions}

This review does not give us enough data to be able to say whether hypertonic crystalloid is better than isotonic and near isotonic crystalloid for the resuscitation of patients with trauma or burns, or those undergoing surgery. However, the confidence intervals are wide and do not 
exclude clinically significant differences. Further trials which clearly state the type and amount of fluid used and that are large enough to detect a clinically important difference are needed.

\section{PLAIN LANGUAGE SUMMARY}

\section{More evidence needed as to the best concentration of crystalloid to use in resuscitation fluids}

Fluid resuscitation is usually given when a patient has lost a lot of blood, but there is continuing uncertainty as to the best sort of fluid to use. Some of the fluids used contain substances classified as "crystalloids", but should the concentration of crystalloids in the fluid be about the same as their concentration in human blood ("isotonic") or higher ("hypertonic")? It is commonly believed that hypertonic crystalloid is the more effective at increasing blood volume but that there could be some disadvantages to using it. This review has assessed the evidence from studies that compared the use of the two types of fluid with patients who had been injured or burned, or were having surgery. Not enough evidence is available, however, to decide which crystalloid concentration is best. More research is needed. 


\section{B A C K G R O U N D}

Fluid resuscitation is a mainstay of the medical management of haemorrhagic hypovolaemia. However, there is continuing uncertainty about the most appropriate fluid (Krausz 1995). Isotonic crystalloid solutions are often used to replace blood loss until a blood transfusion can be administered, but the wish to administer large volumes (advanced trauma life support [ATLS] guidelines suggest two litres of isotonic crystalloid), particularly in the pre-hospital phase when there may be problems with venous access, has stimulated the development of alternative approaches. One such approach is the use of hypertonic saline. Hypertonic solutions are considered to have a greater ability to expand blood volume and thus elevate blood pressure, and can be administered as a small volume infusion over a short time period (Krausz 1995). Infusion of hypertonic saline is believed to act by causing an osmotic shift of fluid from the intracellular and interstitial spaces to the extracellular compartment. The resulting auto-transfusion of fluid increases blood pressure and circulating volume. The use of hypertonic solutions has the potential to provide rapid volume resuscitation but with less interstitial oedema than with isotonic saline solutions (Shackford 1983).

It has also been suggested that hypertonic solutions may be the fluid of choice in hypovolaemic patients with head injuries (Khanna 2000; Peterson 2000; Walsh 1991). Cerebral perfusion pressure (CPP) depends on both intracranial pressure (ICP) and mean arterial blood pressure. (CPP $=$ mean arterial blood pressure mean ICP.) Patients in hypovolaemic shock who have head injuries may require rapid blood pressure elevation to maintain cerebral perfusion pressure, but excessive fluid and salt administration may result in brain swelling with an increase in intracranial pressure. Hypertonic solutions, however, are believed to reduce intracranial pressure by establishing an osmotic gradient across the blood brain barrier that draws water from the brain tissue into the vascular space (Fisher 1992). Hypertonic solutions, therefore, have the potential to restore blood pressure rapidly, but without increasing intracranial pressure. Hypertonic solutions are also thought to be beneficial in preventing the 'water logging' effect when there is interstitial lung injury, for example as occurs both in elective surgery and in trauma.

On the other hand, the use of hypertonic solutions for volume replacement may also have important disadvantages. In situations where haemorrhage is on-going, hypertonic solutions may result in continued bleeding from injured vessels. A potential problem in head injuries is that, in patients with a disrupted blood brain barrier, excess sodium may leak into brain tissue drawing water with it, thus worsening cerebral oedema. At present, there are no clinical ways to assess the integrity of the blood brain barrier. Furthermore, not only could the integrity of the blood brain barrier vary among patients with head injury, but it might also vary in different parts of the brain in a single patient. The possibility that hypertonic fluids may worsen outcome following head injury cannot therefore be dismissed (Krausz 1995, Shenkin 1976).

\section{O B J E C T IVES}

To determine whether hypertonic crystalloid decreases mortality in patients with hypovolaemia with and without head injuries, we conducted a systematic review of randomised controlled trials.

\section{METHODS}

\section{Criteria for considering studies for this review \\ Types of studies}

Randomised controlled trials. Crossover trials were excluded.

\section{Types of participants}

Patients with trauma, burns or surgery. Trials in both the prehospital and hospital setting were included.

\section{Types of interventions}

Trials that compare hypertonic to isotonic and near isotonic crystalloid. Trials of hypertonic crystalloid with an add-on colloid (e.g. hypertonic saline and dextran) are not included. This comparison has been dealt with in a previous systematic review by the Cochrane Injuries Group (Perel 2007).

\section{Types of outcome measures}

The principal outcome measure is mortality from all causes and disability assessed at the end of the follow-up period scheduled for each trial. Disability was assessed using the Glasgow outcome scale (Jennett 1975) which includes the following categories: death, persistent vegetative state, severely disabled, moderately disabled and good recovery. For the purpose of this review, the scale was dichotomised with death, persistent vegetative state and severe disability denoting a poor outcome, and moderate disability and good recovery denoting a good outcome.

Intermediate physiological outcomes were not used for several reasons. Such outcomes are subject to intra and inter-observer variation, they have no face value to patients and relatives, and those seen as appropriate are not stable over time. Also, there would need to exist a strong predictive relationship between the variable and mortality.

\section{Search methods for identification of studies}

The search was last updated in October 2007.

\section{Electronic searches}

We searched the following electronic databases;

- Cochrane Injuries Group's specialised register

- CENTRAL

- MEDLINE

- EMBASE

- National Research Register

- Zetoc.

The original search strategies were based on the terms listed below. The full search strategies for the most recent search update are listed in Appendix 1.

1. Saline solutions hypertonic (MeSH)

2. Isotonic solutions (MeSH)

3. Hypertonic or isotonic or hyperosmotic or hyperoncotic

4. Hypotensive resuscitation

5. \#1 or \#2 or \#3 or \#4

6. random ${ }^{\star}$ 
7. double-blind-procedure (MeSH)

8. \#6 or \#7

9. \#5 and \#8

\section{Data collection and analysis}

\section{Selection of studies}

One reviewer (FB) examined the electronic search results for reports of possibly relevant trials and these reports were retrieved in full. Two reviewers applied the selection criteria independently to the trial reports, resolving disagreements by discussion.

\section{Data extraction and management}

Two reviewers independently extracted information on the following: study quality, number of randomised patients, type of participants and the interventions. The outcome data sought were number of deaths and disability. The reviewers were not blinded to the authors or journal when doing this, as evidence for the value of this is far from conclusive (Berlin 1997). Results were compared and any differences resolved by discussion.

For each trial the relative risk of death and $95 \%$ confidence interval were calculated. The relative risk was chosen as it is more readily applied to the clinical situation.

The groups of trials were examined for statistical evidence of heterogeneity using a chi squared test. As there was no obvious heterogeneity on visual inspection or statistical testing, pooled relative risks (RR) and 95\% confidence intervals (Cls) were calculated using a fixed effects model.

\section{Assessment of risk of bias in included studies}

Since there is evidence that the quality of allocation concealment particularly affects the results of studies (Schulz 1995), two reviewers scored this quality on the scale used by Schulz (Schulz 1995) as shown below, assigning $C$ to poorest quality and A to best quality:

$\mathrm{A}=$ trials deemed to have taken adequate measures to conceal allocation (i.e. central randomisation; numbered or coded bottles or containers; drugs prepared by the pharmacy; serially numbered, opaque, sealed envelopes; or other description that contained elements convincing of concealment).

$\mathrm{B}=$ trials in which the authors either did not report an allocation concealment approach at all or reported an approach that did not fall into one of the other categories.

$\mathrm{C}=$ trials in which concealment was inadequate (such as alternation or reference to case record numbers or to dates of birth)

In addition, data was extracted on blinding and loss to followup. Where the method used to conceal allocation was not clearly reported, the author was contacted, if possible, for clarification. We then compared the scores allocated and resolved differences by discussion.

\section{RES U L T S}

\section{Description of studies}

Eighteen randomised controlled trials were identified by the searches. However, four (Gunn 1989; McGough 1990; Younes 1988a;
Younes 1988b) did not provide data on the outcomes specified in the review. Details of these studies are also reported in the table of included studies for completeness.

In the 14 trials reported in the meta-analysis, patients with burns were included in three $(n=72)$ (Bortolani 1996; Caldwell 1979; Jelenko 1978), patients undergoing surgery in five $(n=230)$ (Croft 1992; Cross 1989; Jarvela 2002; Shackford 1983; Shackford 1987) and trauma patients in six $(n=654)$ (Cooper 2004; Simma 1998; Vassar 1990; Vassar 1993a; Vassar 1993b; Younes 1992).

Eleven trials compared hypertonic saline versus Ringer's lactate (Bortolani 1996; Caldwell 1979; Cooper 2004; Croft 1992; Jelenko 1978; Shackford 1983; Shackford 1987; Simma 1998; Vassar 1990; Vassar 1993a; Vassar 1993b), and the rest compared hypertonic saline with normal saline.

For more detailed descriptions of individual studies, please see the table of included studies. No additional studies were identified for this latest update.

\section{Risk of bias in included studies}

Allocation concealment was judged to be adequate in five trials (Cooper 2004; Simma 1998; Vassar 1990; Vassar 1993a; Vassar 1993b), inadequate in three (Caldwell 1979; Shackford 1983; Shackford 1987), and unclear in the rest. Five trials reported the use of identical bags or containers for the fluids, so that staff were blinded to the identify of the solutions (Cooper 2004; Cross 1989; Vassar 1990; Vassar 1993a; Vassar 1993b).

\section{Effects of interventions}

Death was reported either in the paper, or the information was obtained by contacting the researcher, in 14 studies. Data on death were not obtained for four trials (Gunn 1989; McGough 1990; Younes 1988a; Younes 1988b). Data on disability was obtained from the author of one trial (Cooper 2004).

Due to the clinical heterogeneity of the different patient groups it was felt to be inappropriate to pool them; therefore, only the results for the subgroups are given. The pooled relative risk for death in trauma patients was 0.84 (95\% Cl 0.69 to 1.04 ), for patients with burns 1.49 ( $95 \% \mathrm{Cl} 0.56$ to 3.95$)$ and for patients undergoing surgery 0.51 (95\% $\mathrm{Cl} 0.09$ to 2.73). Only one trial gave data on disability (Cooper 2004) and the relative risk for a poor outcome was 1.00 (95\% $\mathrm{Cl} 0.82$ to 1.22 ).

\section{DISCUSSION}

This review does not give us enough data to be able to say whether hypertonic crystalloid is better than isotonic crystalloid for the resuscitation of patients with trauma or burns, or those undergoing surgery. However, the confidence intervals are wide and do not exclude clinically significant differences between hypertonic and isotonic crystalloid. A previous review (Perel 2007) found there was a trend towards a favourable effect on mortality for colloids in hypertonic crystalloid compared to isotonic crystalloids. However, those results are compatible with the play of chance.

We chose not to pool the results of the burns, surgery and trauma patients, as we felt these groups were too clinically heterogeneous. Bleeding and fluid management in patients undergoing elective 
surgery would tend to be more controlled and, therefore, different to that in trauma patients.

Most of the trials are small and quality was judged to be adequate in only five of them. There was variation in the type of participants, and length of follow-up, and little standardisation in terms of fluid regimes. Also some of the trials were old. Although older trials will not necessarily be of poorer quality, it may be that treatment protocols have subsequently altered, making these trials less relevant to current clinical practice. Indeed in the 1970s and 1980 s there were few protocols on fluid resuscitation in the critically ill. Since the late 1980s, there have been more clear guidelines and standardisation of fluid resuscitation regimes, although many areas of contention still exist.

Mortality was selected as the main outcome measure in this systematic review for several reasons. In the context of critical illness, death or survival is a clinically relevant outcome that is of immediate importance to patients, and data on death are reported in many of the studies. Furthermore, one might expect that mortality data would be less prone to measurement error or biased reporting than would data on pathophysiological outcomes. The use of a pathophysiological end-point as a surrogate for an adverse outcome assumes a direct relationship between the two, an assumption that may sometimes be inappropriate. Finally, when trials collect data on a number of physiological end-points, there is the potential for bias, due to the selective publication of end-points showing striking treatment effects.
Hypertonic solutions have been proposed as the fluid of choice in patients with head injuries (Walsh 1991), as they may maintain cerebral perfusion pressure without causing brain swelling with an increase in intracranial pressure. However, we found only one small trial (Simma 1998) among people with head injuries.

\section{AUTHORS' CONCLUSIONS}

\section{Implications for practice}

This review does not provide any evidence that hypertonic crystalloid is better than isotonic crystalloid, but it does not rule out clinically important differences.

\section{Implications for research}

Further trials are needed comparing hypertonic to isotonic crystalloid. These trials should be multi-centre prospective randomised controlled trials, that are large enough to detect a clinically important difference. Clinically relevant outcomes such as mortality should be used and trials should specify the type and amount of fluid used.

\section{ACKNOWLEDGEMENTS}

Thanks to Reinhard Wentz for help with the searches and to Phil Alderson for overseeing the editorial process. Thanks also to E Akpa for assistance during the review process. 


\section{R E F E R E N C E S}

\section{References to studies included in this review}

Bortolani 1996 \{published data only\}

Bortolani A, Governa M, Barisoni D. Fluid replacement in burned patients. Acta Chirurgiae Plasticae 1996;38(4):132-6.

Caldwell 1979 \{published data only\}

Caldwell FT, Bowser BH. Critical Evaluation of Hypertonic Solutions to Resuscitate Severely Burned Children. Annals of Surgery 1979;18(5):546-52.

\section{Cooper 2004 \{published data only\}}

Cooper J, Myles P, McDermott F, Murray L, Laidlaw J, Cooper G, et al. Prehospital hypertonic saline resuscitation of patients with hypotension and severe traumatic brain injury. Journal of the American Medical Association 2004;291(11):1350-7.

\section{Croft 1992 \{published data only\}}

Croft D, Dion YM, Dumont M, Langlois D. Cardiac compliance and effects of hypertonic saline. Canadian Association of General Surgeons 1992;35(2):139-44.

\section{Cross 1989 \{published data only\}}

Cross JS, Gruber DP, Burchard KW, Singh AK, Moran JM, Gann DS. Hypertonic saline fluid therapy following surgery: a prospective study. Journal of Trauma 1989;29(6):817-26.

\section{Gunn 1989 \{published data only\}}

Gunn ML, Hansbrough JF, Davis JW, Furst SR, Field TO. Prospective, randomized trial of hypertonic sodium lactate versus Ringer's solution for burn shock resuscitation. Journal of Trauma 1989;29(9):1261-7.

\section{Jarvela 2002 \{published data only\}}

Jarvela K, Kaukinen S. Hypertonic saline (7.5\%) after coronary artery bypass grafting. European Journal of Anaesthesiology 2001;18(2):100-7.

Jarvela K, Kaukinen S. Hypertonic saline (7.5\%) decreases perioperative weight gain following cardiac surgery. Journal of Cardiothoracic and Vascular Anesthesia 2002;16(1):43-6.

* Jarvela K, Koskinen M, Kaukinen S, Koobi T. Effects of hypertonic saline (7.5\%) on extracellular fluid volumes compared with normal saline $(0.9 \%)$ and $6 \%$ hydroxyethly starch after aortocoronary bypass graft surgery. Journal of Cardiothoracic and Vascular Anesthesia 2001;15(2):210-15.

\section{Jelenko 1978 \{published data only\}}

Jelenko C, Wheeler ML, Calloway D, Divilio T, Bucklen KR, Holdredge TD. Shock and resuscitation II: volume repletion with minimal edema using the "HALFD" method. JACEP 1978;7(9):326-33.

\section{McGough 1990 \{published data only\}}

McGough EK, Kirby RR. Hypertonic saline for intraoperative fluid therapy. Critical Care Medicine 1990;18(4):5193.

\section{Shackford 1983 \{published data only\}}

Shackford SR, Sise MJ, Fridlund PH, Rowley WR, Peters RM, Virgilio RW, Brimm JE. Hypertonic sodium lactate versus lactated ringers solution for intravenous fluid therapy in operations on the abdominal aorta. Surgery 1983;94(1):41-51.

\section{Shackford 1987 \{published data only\}}

Shackford SR, Fortlage DA, Peters RM, HollingsworthFridlund, Sise MJ. Serum osmolar and electrolyte changes associated with large infusions of hypertonic sodium lactate for intravascular volume expansion of patients undergoing aortic reconstruction. Surgery, Gynecology \& Obstetrics 1987;164(2):127-136.

\section{Simma 1998 \{published data only\}}

Simma B, Burga R, Falk M, Sacher P, Fanconi S. A prospective, randomized, and controlled study of fluid management in children with severe head injury: lactated ringer's solution versus hypertonic saline. Critical Care Medicine 1998;26(7):1265-70.

Simma B, Burger R, Falk M, Sacher P, Torresani T, Fanconi S. The release of antidiuretic hormone is appropriate in response to hypovolemia and/or sodium administration in children with severe head injury: A trial of lactated ringer's solution versus hypertonic saline. Anesthesia and Analgesia 2001;92(3):641-5.

\section{Vassar 1990 \{published data only\}}

Vassar MJ, Perry CA, Holcroft JW. Analysis of potential risks associated with $7.5 \%$ sodium chloride resuscitation of traumatic shock. Archives of Surgery 1990;125(10):1309-15.

\section{Vassar 1993a \{published data only\}}

Vassar MJ, Perry CA, Holcroft JW. Prehospital resuscitation of hypotensive trauma patients with $7.5 \% \mathrm{NaCl}$ versus $7.5 \% \mathrm{NaCl}$ with added dextran: a controlled trial. The Journal of Trauma 1993;34(5):622-633.

\section{Vassar 1993b \{published data only\}}

Vassar MJ, Fischer RP, O'Brien PE, Bachulis BL, Chambers JA, Hoyt DB, Holcroft JW. A multicenter trial for resuscitation of injured patients with $7.5 \%$ sodium chloride. Arch Surg 1993;128:1003-1013.

\section{Younes 1988a \{published data only\}}

Younes RN, Aun F, Birolini D, Kawahara NT, Takeuti M, Casale L, Accioly C, Szajnbok I, Brito N. Initial treatment of hypovolemic patients with $7.5 \%$ solution of $\mathrm{NaCl}$ [O Tratamento inicial de pacientes hipovolemicos: Emprego da solucao hipertonica de $\mathrm{NaCl}$ a 7.5\%]. Rev. Hosp. Clin. Fac. Med. S. Paulo 1988;43(3):138-141.

\section{Younes 1988b \{published data only\}}

Younes R, Bechara M, Langer B, Aun F, Birolini D, Kuznieck S, Guimaraes P. Hypertonic saline $7.5 \%$ in the prevention of hypotension in post abdominal aorta unclamping [Emprego da solucao hipertonica de $\mathrm{NaCl}$ a $7.5 \%$ na prevencao da hipotensao pos-desclampeamento da aorta abdominal]. Rev Ass Med Brasil 1988;34(5):150-154. 
Younes 1992 \{published data only\}

Younes RN, Aun F, Accioly CQ, Casale LPL, Szajnbok I, Birolini. Hypertonic solutions in the treatment of hypovolemic shock: A prospective, randomized study in patients admitted to the emergency room. Surgery 1992;111(4):380-5.

\section{References to studies excluded from this review}

Fisher 1992 \{published data only\}

Fisher B, Thomas D, Peterson B. Hypertonic saline lowers raised intracranial pressure in children after head trauma. Journal of Neurosurgical Anesthesiology 1992;4(1):4-10.

\section{Holcroft 1987 \{published data only\}}

Holcroft J, Vassar M, Turner J, Derlet R, Kramer G. 3\% NaCl and $7.5 \% \mathrm{NaCl} /$ Dextran 70 in the resuscitation of severely injured patients. Annals of Surgery 1987;206(3):279-87.

\section{Shackford 1998 \{published data only\}}

Shackford SR, Bourguignon PR, Wald SL, Rogers FB, Osler TM, Clark DE. Hypertonic saline resuscitation of patients with head injury: a prospective, randomized clinical trial. Journal of Trauma 1998;44(1):50-8.

\section{Shao 2005 \{published data only\}}

Shao Y, Zhang Y, Peng K, Quan Z. Effects of 7.5\% hypertonic saline on fluid balance after radical surgery for gastrointestinal carcinoma. World J Gastroenterol 2005;11(11):1577-1581.

\section{Additional references}

\section{Berlin 1997}

Berlin JA for the University of Pennsylvania Meta-analysis Blinding Study Group. Does blinding of readers affect the results of meta-analyses?. Lancet 1997;350(9072):185-6.

\section{Jennett 1975}

Jennett B, Bond M. Assessment of outcome after severe brain damage. A practical scale. Lancet 1975;1(7905):480-4.

\section{CHARACTERISTICS OF STUDIES}

Characteristics of included studies [ordered by study ID]

\section{Khanna 2000}

Khanna S, Davis D, Peterson B, Fisher B, Tung H, O'Quigley J, Deutsch R. Use of hypertonic saline in the treatment of severe refractory posttraumatic intracranial hypertension in pediatric traumatic brain injury. Critical Care Medicine 2000;28(4):1144-51.

\section{Krausz 1995}

Krausz MM. Controversies in shock research: hypotonic resuscitation - pros and cons. Shock 1995;3(1):69-72.

\section{Perel 2007}

Perel P, Roberts I. Colloids versus crystalloids for fluid resuscitation in critically ill patients (Cochrane Review). Cochrane Database of Systematic Reviews 2007, Issue 4. [Art. No.: CD000567. DOI: 10.1002/14651858.CD000567.pub3]

\section{Peterson 2000}

Peterson B, Khanna S, Fisher B, Marshall L. Prolonged hypernatremia controls elevated intracranial pressure in head-injured pediatric patients. Critical Care Medicine 2000;28(4):1136-43.

\section{Schulz 1995}

Schulz KF, Chalmers I, Hayes RJ, Altman DG. Empirical evidence of bias. Dimensions of methodological quality associated with estimates of treatment effects in controlled trials. JAMA 1995;273(5):408-12.

\section{Shenkin 1976}

Shenkin HA, Bezier HS, Bouzarth WF. Restricted fluid intake: rational management of the neurosurgical patient. Journal of Neurosurgery 1976;45(4):432-6.

\section{Walsh 1991}

Walsh JC, Zhuang J, Shackford SR. A comparison of hypertonic to isotonic fluid in the resuscitation of brain injury and hemorrhagic shock. Journal of Surgical Research 1991;50(3):284-92.

* Indicates the major publication for the study

\section{Bortolani 1996}

Methods Randomised controlled trial. Method of allocation concealment is not described. No mention of blinding.

Participants
Country: Italy

$\begin{array}{ll}\text { Interventions } & \text { Hypertonic lactated saline }(n=20) \\ \text { 2. Ringer's lactated saline }(n=20)\end{array}$

2. Ringer's lactated saline $(n=20)$

Outcomes Haemodynamic variables. Death. 
Bortolani 1996 (Continued)

Complications.

Notes Length of follow-up not clear.

\section{Risk of bias}

\begin{tabular}{lll}
\hline Bias & Authors' judgement & Support for judgement \\
\hline Allocation concealment? & Unclear risk & B - Unclear \\
\hline
\end{tabular}

Caldwell 1979

\begin{tabular}{ll}
\hline Methods & $\begin{array}{l}\text { Treatments were alternated. } \\
\text { No mention of blinding. }\end{array}$ \\
\hline Participants & $\begin{array}{l}20 \text { children with thermal burns covering } 30 \% \text { or more of the body surface area. } \\
\text { Country: USA }\end{array}$ \\
\hline Interventions & $\begin{array}{l}\text { 1. Hypertonic lactated Ringer's ( } n=17) . \\
\text { 2. Lactated Ringer's ( } \mathrm{n}=20) .\end{array}$ \\
& i.v. treatment discontinued after 48 hrs. \\
\hline Outcomes & $\begin{array}{l}\text { Death. } \\
\text { Haemodynamic variables. }\end{array}$ \\
\hline Notes & $\begin{array}{l}\text { Length of follow-up not clear. } \\
\text { No loss to follow-up reported. }\end{array}$ \\
\hline
\end{tabular}

\section{Risk of bias}

\begin{tabular}{lll}
\hline Bias & Authors' judgement & Support for judgement \\
\hline Allocation concealment? & High risk & C - Inadequate \\
\hline
\end{tabular}

\section{Cooper 2004}

$\begin{array}{ll}\text { Methods } & \text { Double blind randomised controlled trial. } \\ \text { Identical bags of sequentially numbered, computer randomised fluid were packed in groups of } 4 \text { in } \\ \text { each ambulance. }\end{array}$

\begin{tabular}{ll}
\hline Participants & 229 patients with traumatic brain injury. \\
Country: Australia.
\end{tabular}

\begin{tabular}{|c|c|}
\hline Interventions & $\begin{array}{l}\text { 1. } 250 \mathrm{ml} \text { of Hypertonic saline }(7.5 \%) \text {. } \\
\text { 2. } 250 \mathrm{ml} \text { of ringers lactate. }\end{array}$ \\
\hline Outcomes & $\begin{array}{l}\text { Death. } \\
\text { Disability (glasgow outcome scale). } \\
\text { Cognitive score. } \\
\text { Functional independence score. }\end{array}$ \\
\hline
\end{tabular}




\section{Risk of bias}

\begin{tabular}{lll}
\hline Bias & Authors' judgement & Support for judgement \\
\hline Allocation concealment? & Low risk & A - Adequate \\
\hline
\end{tabular}

\section{Croft 1992}

\begin{tabular}{ll}
\hline Methods & $\begin{array}{l}\text { Randomised controlled trial. Patients were divided consecutively, with a random allocation chart. } \\
\text { Method of allocation concealment was not described. } \\
\text { No mention of blinding. }\end{array}$ \\
\hline Participants & $\begin{array}{l}28 \text { patients undergoing major intra-abdominal surgery. Patients with an abnormality of a cardiac valve, } \\
\text { liver failure, pacemaker, shock, septicemia or presence of myocardial ischemia less than 24 hours be- } \\
\text { fore the study were excluded. } \\
\text { Country: Canada. }\end{array}$ \\
\hline Interventions & $\begin{array}{l}\text { 1. Hypertonic saline ( } \mathrm{n}=13) . \\
\text { 2. Isotonic Ringer's lactate ( } \mathrm{n}=15) .\end{array}$ \\
$\begin{array}{l}\text { Preoperatively RL or HS were infused at a rate sufficient to maintain a PAWP and a CVP within } 3 \text { mm Hg } \\
\text { of the initial value. }\end{array}$ \\
\hline Haemodynamic variables. \\
Death.
\end{tabular}

\section{Risk of bias}

\begin{tabular}{lll}
\hline Bias & Authors' judgement & Support for judgement \\
\hline Allocation concealment? & Unclear risk & B - Unclear \\
\hline
\end{tabular}

\section{Cross 1989}

$\begin{array}{ll}\text { Methods } & \text { Randomised double-blind study. Method of allocation concealment not described. } \\ \text { Doctors and nurses directly involved in pt care did not know identity of solutions. }\end{array}$

Participants

20 post-op coronary artery bypass patients. Patients with history of significant arrhythmias, congestive heart failure, renal, hepatic, or pulmonary failure were excluded.

Country: USA

$\begin{array}{ll}\text { Interventions } & \text { Hypertonic saline }(n=11) . \\ & \text { 2. Normal saline }(n=9) . \\ & \text { for } 24 \text { hr period following arrival at ITU. }\end{array}$

Study solutions were initially infused at $100 \mathrm{ml} / \mathrm{hr}$, subsequent rates were adjusted according to the clinical status and were infused to maintain hemodynamic stability.

Outcomes Death.


Cross 1989 (Continued)

Hemodynamic variables.

Notes Follow-up 24 hours.

\section{Risk of bias}

\begin{tabular}{lll}
\hline Bias & Authors' judgement & Support for judgement \\
\hline Allocation concealment? & Unclear risk & B - Unclear \\
\hline
\end{tabular}

Gunn 1989

\begin{tabular}{ll}
\hline Methods & Randomised controlled trial. Method of allocation concealment not described. \\
\hline Participants & $\begin{array}{l}51 \text { adult patients who sustained at least 20\% body surface area burns and who were admitted within } 12 \\
\text { hours of injury. }\end{array}$ \\
\hline Interventions & $\begin{array}{l}\text { 1. Hypertonic sodium lactate } \\
\text { 2. Ringer's lactate. } \\
\text { Intravenous fluid was administered to maintain the urine output at a target rate of 0.5-1.0 cc/kg/hour, } \\
\text { and maintain a minimal or zero base deficit in serial blood gas analyses. }\end{array}$ \\
\hline Outcomes & $\begin{array}{l}\text { Hemodynamic variables. } \\
\text { Enteral intake. }\end{array}$ \\
\hline Notes & $\begin{array}{l}\text { Follow-up was for } 72 \text { hours. High drop-out rate due to need for surgery, excision and grafting. These pa- } \\
\text { tients were not followed up after surgery. }\end{array}$ \\
\hline
\end{tabular}

\section{Risk of bias}

\begin{tabular}{lll}
\hline Bias & Authors' judgement & Support for judgement \\
\hline Allocation concealment? & Unclear risk & D - Not used \\
\hline
\end{tabular}

Jarvela 2002

\begin{tabular}{ll}
\hline Methods & Randomised controlled trial. Patients were randomly allocated according to a list of random digits to 2 \\
& groups. \\
& Blinding not specified.
\end{tabular}
Participants
72 patients undergoing elective coronary artery bypass graft surgery. Patients were excluded if they had a left ventricular ejection fraction less than 0.4 , a serum creatinine more than $130 \mathrm{umol} / \mathrm{L}$, hepatic or renal disease, or continuous medication with diuretics. Country: Finland.
Interventions $\quad$ 1. Hypertonic saline $(7.5 \%)(n=36)$.
2. Normal saline $(0.9 \%)(n=36)$.
Both groups received $4 \mathrm{ml} / \mathrm{kg}$ during 30 minutes, when volume loading was needed during the post- operative warming period in ICU. The infusion was stopped if systemic arterial pressure exceeded 170 $\mathrm{mmHg}$.

Outcomes Hemodynamic variables.
Hypertonic versus near isotonic crystalloid for fluid resuscitation in critically ill patients (Review)
Copyright $\odot 2008$ The Cochrane Collaboration. Published by John Wiley \& Sons, Ltd.


Jarvela 2002 (Continued)

MAP.

Cardiac index.

Notes $\quad$ Follow-up first post-op morning.

\section{Risk of bias}

\begin{tabular}{lll}
\hline Bias & Authors' judgement & Support for judgement \\
\hline Allocation concealment? & Unclear risk & B - Unclear \\
\hline
\end{tabular}

Jelenko 1978

$\begin{array}{ll}\text { Methods } & \text { Randomised controlled trial, method of allocation concealment not described. } \\ & \text { Blinding not mentioned. } \\ & \text { No loss to follow up. }\end{array}$

\begin{tabular}{ll}
\hline Participants & $\begin{array}{l}\text { 12 patients with burns covering more than 20\% of body surface. } \\
\text { Country: USA. }\end{array}$ \\
\hline Interventions & $\begin{array}{l}\text { 1. Hypertonic saline (240MeQ Na+, } 120 \text { MeQ Chloride, } 120 \text { MeQ lactate) ( } n=5) . \\
\text { 2. Ringer's lactate }(n=7) .\end{array}$ \\
\hline Outcomes & $\begin{array}{l}\text { Death. } \\
\text { Hemodynamic variables. }\end{array}$ \\
\hline Notes & Follow-up to the end of resuscitation. \\
\hline Risk of bias & Authors' judgement Support for judgement \\
\hline Bias & Unclear risk $\quad$ B - Unclear \\
\hline Allocation concealment? &
\end{tabular}

\section{McGough 1990}

\begin{tabular}{ll}
\hline Methods & Randomised controlled trial. Method of allocation concealement not described. \\
\hline Participants & 50 patients undergoing total hip arthroplasty, hysterectomy, or radical prostatectomy. \\
\hline Interventions & $\begin{array}{l}\text { 1. Hypertonic saline at } 4 \mathrm{ml} / \mathrm{kg} / \mathrm{hr} . \\
\text { 2. Ringers lactate at } 8 \mathrm{ml} / \mathrm{kg} / \mathrm{hr} .\end{array}$ \\
\hline Outcomes & Complications. \\
\hline Notes & \\
\hline
\end{tabular}

\section{Risk of bias}


McGough 1990 (Continued)

Allocation concealment? Unclear risk B - Unclear

Shackford 1983

Methods Patients were assigned by random number to one of two groups. Allocation was done by list of random numbers read by someone entering the patient into the trial (open list).

No mention of blinding.

\begin{tabular}{ll} 
Participants & $\begin{array}{l}58 \text { patients undergoing aortic reconstruction. } \\
\text { Country: USA. }\end{array}$ \\
\hline Interventions & $\begin{array}{l}\text { 1. Group one received a hypertonic solution }(\mathrm{HSL})(\mathrm{n}=30) . \\
\text { 2. Group two received ringers lactate }(\mathrm{n}=28) . \\
\text { Fluid was given to maintain the cardiac filling pressure within } 3 \text { torr of the preoperative level and the } \\
\text { cardiac output at or above the preoperative level. All pts received } 5 \% \text { dextrose in } 0.25 \mathrm{~N} \text { saline as a } \\
\text { maintenance solutuion. }\end{array}$
\end{tabular}

\begin{tabular}{ll}
\hline Outcomes & $\begin{array}{l}\text { Hemodynamic variables. } \\
\text { Death. }\end{array}$ \\
\hline Notes & Follow-up three days.
\end{tabular}

\section{Risk of bias}

\begin{tabular}{lll}
\hline Bias & Authors' judgement & Support for judgement \\
\hline Allocation concealment? & High risk & C - Inadequate \\
\hline
\end{tabular}

Shackford 1987

Patients were assigned by random number to one of two groups.
Allocation was done by list of random numbers read by someone entering the patient into the trial
(open list).
No mention of blinding.

\begin{tabular}{ll}
\hline Participants & $\begin{array}{l}52 \text { patients undergoing aortic reconstruction. } \\
\text { Country: USA }\end{array}$ \\
\hline Interventions & $\begin{array}{l}\text { 1. Hypertonic lactated saline ( } \mathrm{n}=26) . \\
\text { 2. Ringer's lactate }(\mathrm{n}=26) .\end{array}$ \\
& $\begin{array}{l}\text { During and immediately after the operation fluid was given to maintain the CO equal to preoperative } \\
\text { levels and the cardiac filling pressures within } 3 \text { torr of the preoperative value. Post-op all of the patients } \\
\text { received 5\% dextrose in normal saline as a maintenance solution, this was continued until the first day } \\
\text { post-op. During this same period, additional fluid (either HSL or RL) was given to maintain cardiac fill- } \\
\text { ing pressures and CO at pre-op levels. }\end{array}$
\end{tabular}

\begin{tabular}{ll}
\hline Outcomes & Hemodynamic variables. \\
& Serum compositional changes.
\end{tabular}

Notes $\quad$ Follow-up three days.


Shackford 1987 (Continued)

Risk of bias

\begin{tabular}{lll}
\hline Bias & Authors' judgement & Support for judgement \\
\hline Allocation concealment? & High risk & C-Inadequate \\
\hline
\end{tabular}

Simma 1998

Methods Randomized controlled trial. Randomization was done by an independent investigator. Staff were not blinded to the type of fluid.

Participants head-injured children under the age of 16 with Glasgow coma scores of $<8$. The patients entered the
study at the time when ICP was first measured.
Country: Switzerland.

\begin{tabular}{ll}
\hline Interventions & $\begin{array}{l}\text { 1. Hypertonic saline }(\mathrm{n}=15) . \\
\text { 2. Ringer's lactate }(\mathrm{n}=17) .\end{array}$ \\
& Over 72 hours. \\
\hline Outcomes & $\begin{array}{l}\text { Hemodynamic variables. } \\
\text { Complications. } \\
\text { Length of hospital stay. } \\
\text { Death. }\end{array}$ \\
\hline Notes & Follow-up until discharge from hospital. \\
\hline Risk of bias & Authors' judgement Support for judgement \\
\hline Bias & Unclear risk $\quad$ B - Unclear \\
\hline Allocation concealment? &
\end{tabular}

Vassar 1990

\begin{tabular}{ll} 
Methods & $\begin{array}{l}\text { Randomised controlled trial, allocation concealment unclear. } \\
\text { Double blind study (solutions prepared in identical containers). } \\
\text { No loss to follow up. }\end{array}$ \\
\hline Participants & $\begin{array}{l}59 \text { injured patients were entered into the trial. Participants were emergency department admissions } \\
\text { with trauma and a systolic blood pressure below } 80 \mathrm{~mm} \mathrm{Hg} \text { and were } 18 \text { years or older. } \\
\text { Pregnant women and people with preexisting cardiac, hepatic or renal disease were excluded. } \\
\text { Country: USA }\end{array}$
\end{tabular}

\begin{tabular}{|c|c|}
\hline Interventions & $\begin{array}{l}\text { 1. } 7.5 \% \text { saline }(n=32) \text {. } \\
\text { 2. Ringer's lactate }(n=27) \text {. } \\
\text { Allocated fluids were given as the initial resuscitation fluid in the emergency department. }\end{array}$ \\
\hline Outcomes & $\begin{array}{l}\text { Haemodynamic variables. } \\
\text { Death. }\end{array}$ \\
\hline Notes & Follow-up until discharge from hospital. \\
\hline
\end{tabular}


Vassar 1990 (Continued)

Risk of bias

\begin{tabular}{lll}
\hline Bias & Authors' judgement & Support for judgement \\
\hline Allocation concealment? & Unclear risk & B - Unclear \\
\hline
\end{tabular}

Vassar 1993a

\begin{tabular}{ll} 
Methods & $\begin{array}{l}\text { Randomised controlled double blind trial. Allocation concealed by random sequence of identical con- } \\
\text { tainers. } \\
\\
36 \text { people excluded post randomisation as deemed not to have met eligibility criteria. } \\
\text { No loss to follow up. }\end{array}$ \\
\hline Participants & $\begin{array}{l}169 \text { pre-hosptial trauma patients, who were undergoing ambulance transport to an emergency centre, } \\
\text { had systolic blood pressure } 90 \mathrm{mmHg} \text { or less, and were } 18 \text { years or older. } \\
\text { Exclusions: asystolic, undergoing CPR, lack sinus complex on ECG, more than } 2 \text { hours after trauma, } \\
\text { pregnant, preexisting seizures, bleeding disorder, hepatic, cardiac or renal disease. } \\
\text { Country: USA }\end{array}$
\end{tabular}

Interventions $\begin{aligned} & \text { 1. } 7.5 \% \text { saline }(n=85) . \\ & \text { 2. } 0.9 \% \text { saline }(n=84) . \\ & \text { Participants received } 250 \mathrm{~mL} \text { of the allocated fluid in the pre-hospital setting. Additional isotonic crys- } \\ & \text { talloids were given as needed. }\end{aligned}$

\begin{tabular}{|c|c|c|}
\hline Outcomes & \multicolumn{2}{|c|}{$\begin{array}{l}\text { Deaths reported. } \\
\text { Haemodynamic variables. } \\
\text { Trauma scores and neurological outcome scores. }\end{array}$} \\
\hline Notes & \multicolumn{2}{|c|}{ Follow-up until discharge from hospital. } \\
\hline \multicolumn{3}{|l|}{ Risk of bias } \\
\hline Bias & Authors' judgement & Support for judgement \\
\hline Allocation concealment? & Low risk & A - Adequate \\
\hline
\end{tabular}

\section{Vassar 1993b}

\begin{tabular}{ll}
\hline Methods & Randomised controlled trial, allocation concealed by sequential use of coded identical containers. On- \\
ly the manufacturer could know the treatment assignment. \\
Double blind study. \\
$39 / 233$ patients excluded as deemed not to meet eligibility criteria, unclear from which groups.
\end{tabular}

Participants
tolic blood pressure of $100 \mathrm{mmHg}$ or less and were 18 years or older.
Exclusions: asystolic, undergoing CPR, lack sinus complex on ECG, more than 2 hours after trauma,
pregnant, preexisting seizures, bleeding disorder, hepatic, cardiac or renal disease.
Country: USA

\begin{tabular}{ll}
\hline Interventions & 1. $7.5 \%$ saline. $(n=50)$ \\
& 2. Ringer's lactate. $(n=45)$
\end{tabular}


Vassar 1993b (Continued)

Participants received $250 \mathrm{~mL}$ of the allocated fluid in the pre-hospital setting. Additional isotonic crystalloids were given as needed.

\section{Deaths reported.}

Haemodynamic variables.

Trauma scores and neurological outcome scores.

Notes Follow-up until discharge from hospital.

\section{Risk of bias}

\begin{tabular}{lll}
\hline Bias & Authors' judgement & Support for judgement \\
\hline Allocation concealment? & Low risk & A - Adequate \\
\hline
\end{tabular}

\section{Younes 1988a}

\begin{tabular}{ll}
\hline Methods & Random assignment. Method of allocation concealment not mentioned. \\
\hline Participants & 33 patients admitted to the emergency ward in hypovolemic shock (mean arterial pressure $<60 \mathrm{mmHg}$ ) \\
\hline Interventions & $\begin{array}{l}\text { 1. Hypertonic } 7.5 \% \text { saline }(\mathrm{n}=18) . \\
\text { 2. Isotonic } \mathrm{NaCl}(\mathrm{n}=15) .\end{array}$ \\
& $\begin{array}{l}\text { Both fluids received at infusion rate of } 10 \mathrm{ml} / \text { minute, over } 15 \text { minutes. No other fluid was given after the } \\
\text { infusion unless MAP fell below } 80 \mathrm{mmHg} \text {, until typed-crossmatched blood was available. Patients were } \\
\text { excluded from the study as soon as given fluid or blood. }\end{array}$
\end{tabular}

\begin{tabular}{ll}
\hline Outcomes & MAP \\
\hline Notes & Length of follow-up not recorded.
\end{tabular}

\section{Risk of bias}

\begin{tabular}{lll}
\hline Bias & Authors' judgement & Support for judgement \\
\hline Allocation concealment? & Unclear risk & B - Unclear \\
\hline
\end{tabular}

Younes $1988 \mathrm{~b}$

\begin{tabular}{ll}
\hline Methods & Random assignment. Method of allocation concealment not mentioned. \\
\hline Participants & 31 patients admitted for abdominal aorta reconstructive surgery. \\
\hline Interventions & $\begin{array}{l}\text { 1. Hypertonic } 7.5 \% \mathrm{NaCl},(\mathrm{n}=18) \\
\text { 2. Isotonic } 0.9 \% \text { saline }(\mathrm{n}=13)\end{array}$ \\
Both groups received fluid as the volume of $4 \mathrm{ml} / \mathrm{kg}$ of body weight, infused during 15 minutes. The in- \\
fusion was started 2 minutes before the release of the aortic clamp.
\end{tabular}


Younes 1988b (Continued)
Notes
Length of follow up not recorded.

\section{Risk of bias}

\begin{tabular}{lll}
\hline Bias & Authors' judgement & Support for judgement \\
\hline Allocation concealment? & Unclear risk & B - Unclear \\
\hline
\end{tabular}

\section{Younes 1992}

\begin{tabular}{ll}
\hline Methods & Randomised 'in a double blind fashion'. \\
& Blinding by use of similar bottles. \\
& No loss to follow up.
\end{tabular}

\begin{tabular}{ll}
\hline Participants & 70 emergency department admissions, who had a systolic blood pressure of less than $80 \mathrm{~mm} \mathrm{Hg}$ and \\
were 19 years and older. \\
Exclusions: pregnant, preexisting cardiac or metabolic disease.
\end{tabular}

Interventions 1. $7.5 \%$ saline $(n=35)$.

2. $0.9 \%$ saline $(n=35)$.

Allocated fluid was for initial bolus of $250 \mathrm{~mL}$, followed by isotonic crystalloids as needed.

\begin{tabular}{ll}
\hline Outcomes & $\begin{array}{l}\text { Deaths reported. } \\
\text { Fluid balance. }\end{array}$ \\
\hline Notes & Follow-up until discharge from hospital.
\end{tabular}

\section{Risk of bias}

\begin{tabular}{lll}
\hline Bias & Authors' judgement & Support for judgement \\
\hline Allocation concealment? & Unclear risk & B - Unclear \\
\hline
\end{tabular}

MAP = mean arterial pressure.

$I C U=$ Intensive care unit.

PCWP = Pulmonary capillary wedge pressure.

Characteristics of excluded studies [ordered by study ID]

\begin{tabular}{ll}
\hline Study & Reason for exclusion \\
\hline Fisher 1992 & Cross-over study. \\
\hline Holcroft 1987 & The study was not randomised. Fluid was administered depending on the attending surgeon. \\
\hline Shackford 1998 & Study compared hypertonic fluid versus hypotonic. \\
\hline Shao 2005 & The patients were 'assigned' and not randomised. \\
\hline
\end{tabular}


DATA AND ANALYSES

Comparison 1. Hypertonic versus isotonic crystalloid

\begin{tabular}{lllll}
\hline $\begin{array}{l}\text { Outcome or subgroup } \\
\text { title }\end{array}$ & $\begin{array}{l}\text { No. of } \\
\text { studies }\end{array}$ & $\begin{array}{l}\text { No. of } \\
\text { partici- } \\
\text { pants }\end{array}$ & Statistical method & Effect size \\
\hline 1 Death & 14 & & Risk Ratio (M-H, Fixed, 95\% Cl) & Subtotals only \\
\hline 1.1 Trauma & 6 & 651 & Risk Ratio (M-H, Fixed, 95\% Cl) & $0.84[0.69,1.04]$ \\
\hline 1.2 Burns & 3 & 89 & Risk Ratio (M-H, Fixed, 95\% Cl) & $1.49[0.56,3.95]$ \\
\hline 1.3 Surgery & 5 & 230 & Risk Ratio (M-H, Fixed, 95\% Cl) & $0.51[0.09,2.73]$ \\
\hline 2 Poor outcome (GOS) & 1 & 226 & Risk Ratio (M-H, Fixed, 95\% Cl) & $1.0[0.82,1.22]$ \\
\hline 2.1 Trauma & 1 & 226 & Risk Ratio (M-H, Fixed, 95\% Cl) & $1.0[0.82,1.22]$ \\
\hline
\end{tabular}

Analysis 1.1. Comparison 1 Hypertonic versus isotonic crystalloid, Outcome 1 Death.

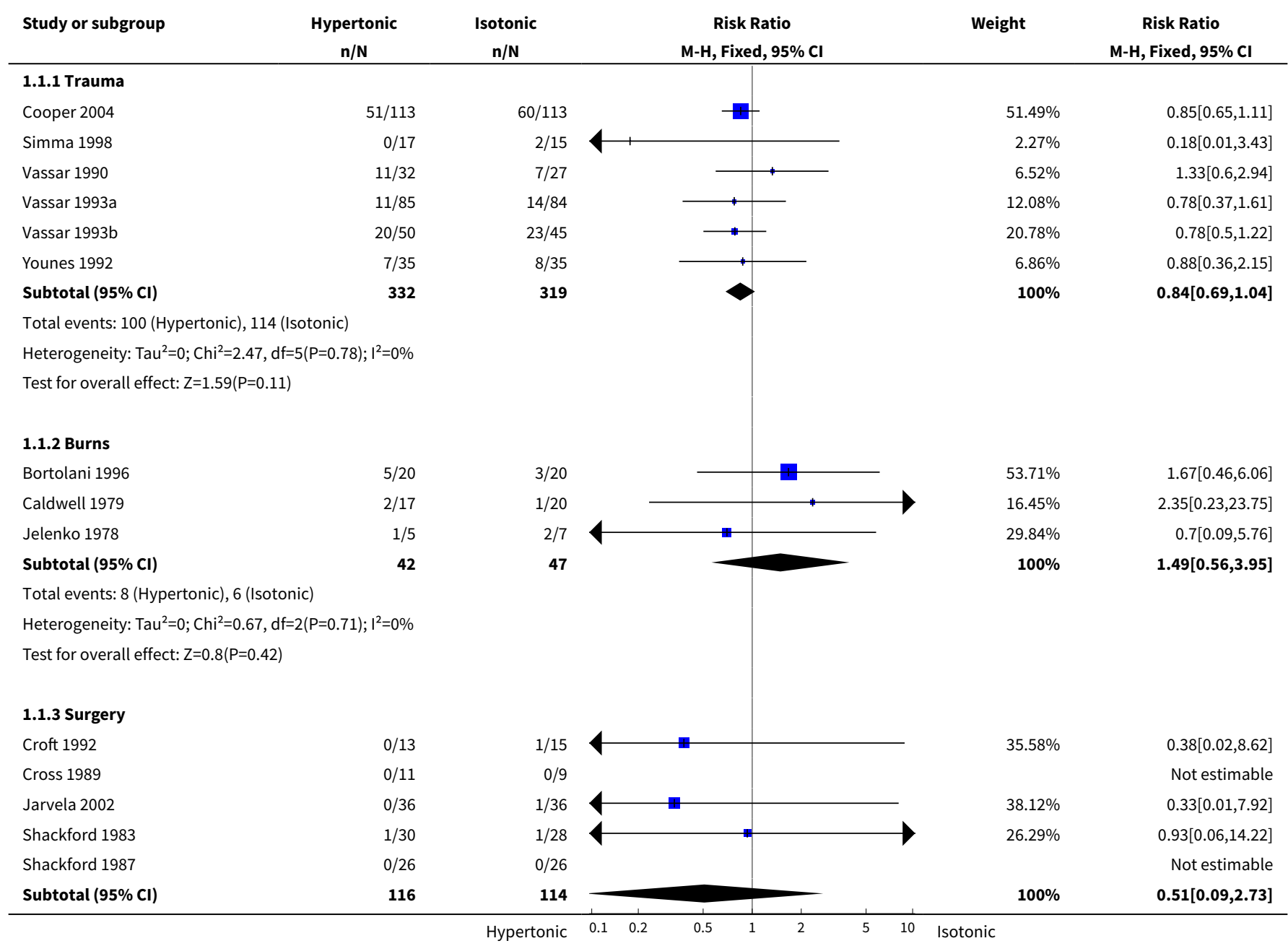




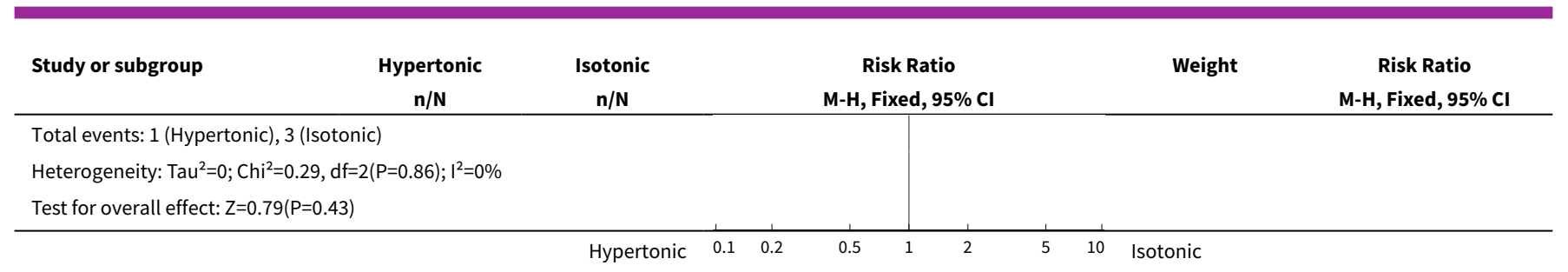

\section{Analysis 1.2. Comparison 1 Hypertonic versus isotonic crystalloid, Outcome 2 Poor outcome (GOS).}

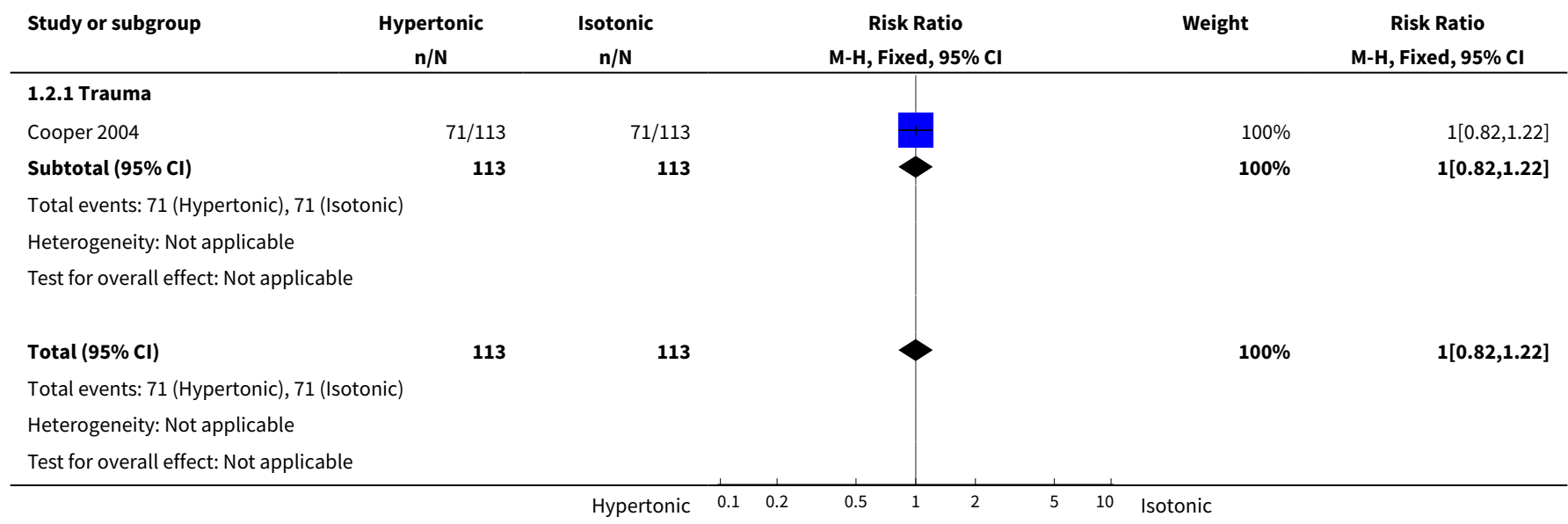

\section{APPENDICES}

\section{Appendix 1. Search strategy}

\section{Injuries Specialised Register; searched 03-10-07}

(hypertonic* or isotonic* or hyperosmotic* or hyperoncotic ${ }^{\star}$ ) or ("hypotensive resuscitation") or ("Isotonic Solutions")

CENTRAL up to issue 3, 2007

Searched 02-10-07

\#1 exp Saline Solution, Hypertonic/

\#2 exp Isotonic Solutions/

\#3 hypertonic ${ }^{*}$ or isotonic ${ }^{\star}$ or hyperosmotic* or hyperoncotic ${ }^{*}$

\#4 hypotensive next resuscitation

\#5 \#1 or \#2 or \#3 or \#4

MEDLINE up to Sept, week 3, 2007

Searched 02-10-07

1. exp Saline Solution, Hypertonic/

2. exp Isotonic Solutions/

3. (hypertonic\$ or isotonic\$ or hyperosmotic\$ or hyperoncotic\$).ab,ti.

4. hypotensive resuscitation.mp.

5.1 or 2 or 3 or 4

6 . (2004\$ or $2005 \$$ or $2006 \$$ or $2007 \$)$.em.

7.5 and 6

8. (randomised or randomized or randomly or random order or random sequence or random allocation or randomly allocated or at random or controlled clinical trial\$).tw,hw. 
(Continued)

9. clinical trial.pt.

10. 8 or 9

11. exp models, animal/

12. exp Animals/

13. exp Animal Experimentation/

14. exp Disease Models, Animal/

15. exp Animals, Laboratory/

16. or/11-15

17. Humans/

18. 16 not 17

19. 10 not 18

20. 7 and 19

EMBASE up to Sept (week 39), 2007

Searched 02-10-07

1. exp Hypertonic Solution/

2. exp Isotonic Solution/

3. (hypertonic $\$$ or isotonic\$ or hyperosmotic $\$$ or hyperoncotic\$).ab,ti.

4. hypotensive resuscitation.mp.

5. or/1-4

6. exp animal model/

7. Animal Experiment/

8. $\exp$ ANIMAL/

9. exp Experimental Animal/

10.6 or 7 or 8 or 9

11. Human/

12. 10 not 11

13. (randomised or randomized or randomly or random order or random sequence or random allocation or randomly allocated or at random or controlled clinical trial\$).tw, hw.

14. exp clinical trial/

15. 13 or 14

16. 15 not 12

17.5 and 16

18. (2004\$ or $2005 \$$ or $2006 \$$ or $2007 \$) . e m$.

19. 17 and 18

NRR up to issue 3, 2007

Searched 03-10-07

\#1 hypertonic ${ }^{\star}$ or isotonic* or hyperosmotic * or hyperoncotic ${ }^{\star}$ )

\#2 (hypotensive next resuscitation)

\#3 (isotonic next solution*)

\#4 (hypertonic next solution*)

\#5 SALINE SOLUTION HYPERTONIC explode all trees (MeSH)

\#6 ISOTONIC SOLUTIONS explode all trees (MeSH)

\#7 \#1 or \#2 or \#3 or \#4 or \#5 or \#6

Zetoc (2004-2007)

searched 03-10-07

Hypertonic* random*

Or

Isotonic* random*

Or

Hypotensive resusc * random * 


\section{FEEDBACK}

\section{Lactated Ringer's not isotonic}

\section{Summary}

Lactated Ringer's solution is not a truly isotonic fluid. In one report (Tommasino C, Moore S, Todd MM. Crit Care Med 1988;16 p867) the measured osmolality was stated to be approximately $254 \mathrm{mosm} / \mathrm{l}$ while the calculated osmolality was $273 \mathrm{mosm} / \mathrm{l}$.

The treatment of traumatized patients will include the infusion of many literes of crystalloids during the first hours. In comparison, the 250 $\mathrm{ml}$ of lactated Ringer's or saline used at intervention in the studies concerned probably does not matter very much. The problem addressed by the review, rather than one of "isotonic versus hypotonic", may be more precisely formulated as something like "early supplementation or not" of hypertonic fluid to the continued use of many liters of a weakly hypotonic fluid.

The hypothesis that $250 \mathrm{ml}$ of hypertonic fluid is beneficial, may easily lead to the idea that many litres of a hypotonic fluid is detrimental. Or is the hypertonic fluid of benefit only when it is added to adjust for the hypotonic one? Will a test with really isotonic crystalloid do better than the hypotonic one and show the supplementation with hypertonic fluid not only to be unnecessary, but even harmful?

The reports often conceal the true nature of the fluids used behind designations like "conventional isotonic solutions" or "standard of care", and the amount of fluid given after arrival in hospital may not be stated.

Implications for research is that studies with the continued use of truly isotonic solutions have to be done to decide whether hypertonic or weakly hypotonic solutions are beneficial or detrimental. The nature and amount of fluids used in future studies should be clearly stated.

I certify that I have no affiliations with or involvement in any organisation or entity with a direct financial interest in the subject matter of my criticisms.

\section{Reply}

We agree that lactated Ringer's is not a truly isotonic fluid and have, therefore, changed the title of the review to reflect this. The title is now 'Hypertonic versus near isotonic crystalloid for fluid resuscitation in critically ill patients'.

We also agree that the nature and amount of fluids used in future studies should be clearly stated, and have included a statement to this effect in the conclusions.

\section{Contributors}

Comment by Per Størset (anesthesiologist), December 2002.

Reply from Frances Bunn, May 2004.

\section{WHAT'S NEW}

\begin{tabular}{lll}
\hline Date & Event & Description \\
\hline 10 July 2008 & Amended & Converted to new review format. \\
\hline
\end{tabular}

\section{H I S T O R Y}

Protocol first published: Issue 2, 2000

Review first published: Issue 4, 2000

\begin{tabular}{lll}
\hline Date & Event & Description \\
\hline 20 February 2008 & New search has been performed & $\begin{array}{l}\text { This review was originally published in the Cochrane Library in } \\
\text { 2000. It has subsequently been updated in 2001, 2004, and, most } \\
\text { recently, 2008. No new studies were added in the most recent } \\
\text { update. }\end{array}$ \\
& & \\
\hline
\end{tabular}




\section{CONTRIBUTIONS OF AUTHORS}

FB screened citations for eligibility, obtained references, contacted authors, extracted data, entered data and wrote up the review. IR helped to write the review. RT commented on the protocol and review. DT screened citations for eligibility.

\section{DECLARATIONS OF INTEREST}

None known.

\section{SOURCES OF SUPPORT}

\section{Internal sources}

- University of Hertfordshire, UK.

\section{External sources}

- NHS Research and Development, UK.

\section{N D EX TERMS}

\section{Medical Subject Headings (MeSH)}

*Plasma Substitutes; Critical Illness; Hypertonic Solutions [*therapeutic use]; Hypovolemia [mortality] [*therapy]; Isotonic Solutions [therapeutic use]; Randomized Controlled Trials as Topic; Rehydration Solutions [*therapeutic use]

\section{MeSH check words}

Humans 